\title{
Deteksi Frekuensi Distribusi Timbal Dalam Darah Pekerja Pengisi Bahan Bakar: Studi Kasus SPBU di Plaju, Sumatera Selatan.
}

\author{
Yuanita Windusari ${ }^{1 *}$, Intan Nurul Aini ${ }^{2}$, Arum Setiawan², Entin Nur Aetin ${ }^{2}$ \\ ${ }^{1}$ Jurusan Kesehatan Lingkungan Fakultas Kesehatan Masyarakat Universitas Sriwijaya \\ ${ }^{2}$ Jurusan Biologi Fakultas Matematika dan Ilmu Pengatahuan Alam Universitas Sriwijaya \\ *Coressponding author : ywindusari@yahoo.com
}

info Artikel : Diterima Desember 2018 ; Disetujui Maret 2019 ; Publikasi April 2019

\begin{abstract}
ABSTRAK
Latar belakang: Timbal $(\mathrm{Pb})$ sebagai logam berat pernah dijadikan sebagai bahan aditif pada bensin. $\mathrm{Pb}$ dalam bentuk tetraetiltimbal $\left(\mathrm{Pb}_{2}\left(\mathrm{C}_{2} \mathrm{H}_{5}\right)_{4}\right)$ yang membantu proses pembakaran pada mesin kendaraan menjadi lebih halus dan cepat. $\mathrm{Pb}$ pada bahan bakar berdampak merugikan bagi lingkungan sekitar termasuk manusia. Pada saat pembakaran, $\mathrm{Pb}$ dilepas ke udara bersamaan dengan asap kendaraan. Senyawa yang dilepaskan tersebut berdampak negatif bagi kesehatan. Efek pertama keracunan timbal kronis sebelum mencapai organ target adalah gangguan haemoglobin dan berakibat pada menurunnya kadar haemoglobin. Gangguan anemia akan timbul bila kandungan $\mathrm{Pb}$ lebih dari $70 \mathrm{ug} / \mathrm{dl}$ atau setara $0,7 \mathrm{ppm}$. Berkaitan dengan efek negatif $\mathrm{Pb}$ dalam bensin, maka sangatlah penting untuk mendeteksi dan memperkirakan frekuensi kadar $\mathrm{Pb}$ dalam dalam darah pekerja pengisi bahan bakar (pekerja SBPU) yang melakukan kontak langsung dengan bahan bakar.

Metode: Sebanyak 11 orang pekerja pengisi bahan bakar dan 2 orang pegawai administrasi menjadi responden dan kontrol dalam penelitian ini. Kriteria inklusi adalah jenis kelamin laki-laki dan perempuan dengan usia 2040 tahun, dan kriteria eksklusi adalah yang tidak bersedia menjadi responden. Responden mengisi kuesioner dan di wawancara untuk mengetahui riwayat kesehatan, kemudian dilakukan pengambilan darah untuk dianalisis. Penentuan titik sampling berdasarkan metode purposive sampling dengan kriteria Stasiun Pengisian Bahan Bakar (SPBU) berada di daerah padat kendaraan dan beroperasi selama 24 jam.

Hasil: Analisis darah menggunakan SSA Shimadzu 6300 menunjukkan kadar $\mathrm{Pb}<2.995 \mathrm{ng} / \mathrm{nl}$. Hal ini mengindikasi tidak adanya $\mathrm{Pb}$ dalam darah responden. Tidak terdeteksinya $\mathrm{Pb}$ dalam darah diduga akibat responden terpapar $\mathrm{Pb}$ dalam jangka waktu singkat, penggunaan peralatan keselamatan (APD) saat bekerja, serta dapat mengindikasi rendahnya kadar $\mathrm{Pb}$ pada bahan bakar kendaraan bermotor.

Simpulan: Tidak terdeteksinya $\mathrm{Pb}$ dalam darah responden tidak berarti mengabaikan keberadaan $\mathrm{Pb}$ di dalam bahan bakar. Sangatlah penting untuk melakukan pemeriksaan kandungan kadar $\mathrm{Pb}$ secara rutin pada semua pekerja SPBU akibat resiko paparan $\mathrm{Pb}$ bagi kesehatan.
\end{abstract}

Kata kunci: timbal; pekerja pengisi bahan bakar; bahan bakar bensin; darah; SSA Shimadzu 6300

\section{ABSTRACT}

Title: Frequency Distribution Of Leads In Blood Workers Filling Fuel: Case Study Of Fueling Station at Plaju, South Sumatra

Background: Lead $(\mathrm{Pb})$ as heavy metal has been used as an additive in gasoline. Pb in the form of tetra ethyl lead (Pb2 (C2H5) 4) which helps the combustion process on the vehicle engine so that the engine sound becomes smoother and faster. Pb on fuel has a negative impact on the surrounding environment including humans. When burning in a vehicle engine, $\mathrm{Pb}$ is released into the air along with vehicle smoke. The compound released has a negative impact on health. The first of chronic Pb poisoning before reaching the target organ is the presence of haemoglobin synthesis disorder so that the haemoglobin level decreases. Anemic disorders will occur if the Pb content is more than $70 \mathrm{ug} / \mathrm{dl}$ or equal to $0.7 \mathrm{ppm}$. In connection with the negative effects of Pb in gasoline, it is very important to detect and estimate the frequency of Pb levels in the blood of fuel filling workers who make direct contact with fuel. 
Methods: As many as 11 fuel filling workers and 2 administrative employees became respondents and controls in this study. The inclusion criteria were the sex of men and women aged 20-40 years, and the exclusion criteria were workers who were not respondents available. Respondents filled out the questioner and continued the interview to find out their medical history, then taking blood to be analyzed. Determination of sampling points based on purposive sampling method with the criteria of the Fuel Filling Station is in a crowded area of the vehicle and operates for 24 hours.

Results: The results of blood analysis using SSA Shimadzu 6300 showed Pb level $<2.995 \mathrm{ng} / \mathrm{nl}$. This proves that $\mathrm{Pb}$ is not found in the blood of the respondent. No detection of $\mathrm{Pb}$ in the blood because the respondent was exposed to Pb in a short period of time, the use of safety equipment while working, and an indication of the low levels of $\mathrm{Pb}$ in motor vehicle fuel

Conclusion: Not detecting lead in the respondent's blood does not mean ignoring the presence of lead in the fuel. It is very important to check the lead content regularly on all gas station workers due to the risk of lead exposure to health.

Keywords: lead; refueling worker; additive to gasoline; blood; SSA Shimadzu 6300

\section{PENDAHULUAN}

Timbal $(\mathrm{Pb})$ merupakan salah satu logam berat yang digunakan masyarakat untuk beberapa jenis keperluan, salah satunya sebagai bahan aditif pada bensin karena keberadaan senyawa tetraetiltimbal atau $\mathrm{Pb}_{2}\left(\mathrm{C}_{2} \mathrm{H}_{5}\right)_{4}$ dalam bensin berpengaruh pada proses pembakaran yang menjadi lebih cepat dan lebih halus serta mampu mengurangi ketukan sehingga kinerja bahan bakar bensin dalam proses pembakaran menjadi lebih baik ${ }^{1}$.

Berkenaan dengan alasan diatas, maka sekitar tahun 1990-an penggunaan $\mathrm{Pb}$ di dalam bensin sedang tinggi-tingginya dilakukan di beberapa negara, termasuk di Indonesia. Pada tahun 1995-2000, di Jakarta akan terjadi peningkatan penggunaan kendaraan bermotor yang menggunakan bensin bertimbal sehingga konsentrasi $\mathrm{Pb}$ di udara Jakarta cenderung mengalami kenaikan. Adapun konsentrasi $\mathrm{Pb}$ di udara Jakarta pada tahun 2000 melewati ambang batas standar $\mathrm{Pb}$ setiap $1 \mathrm{jam}(1 \mu \mathrm{g} / \mathrm{m} 3)$ yaitu sebesar $1,3 \mu \mathrm{g} / \mathrm{m} 3$. Sayangnya, ternyata $\mathrm{Pb}$ yang ada di udara sangat berdampak buruk jika masuk ke dalam tubuh manusia karena $\mathrm{Pb}$ memiliki dampak yang besar terhadap morfologi eritrosit ${ }^{2}$.

Bentuk normal eritrosit adalah bikonkaf dengan warna oren kemerahan, tidak memiliki inti. Akibat paparan $\mathrm{Pb}$, bentuk normal eritrosit akan berubah seperti adanya basophilic stippling (sel stipel basofil). Basophilic stippling adalah titik kecil berwarna biru atau ungu pada eritrosit yang berdampak pada terjadinya anemia. Basophilic stippling terdeteksi melalui apusan darah tepi (blood smear $)^{3}$

Keberadaan $\mathrm{Pb}$ di dalam darah juga mempengaruhi kadar hemoglobin $(\mathrm{Hb})$ di dalam darah itu sendiri. Akumulasi $\mathrm{Pb}$ pada eritrosit mampu menghambat proses sintesa $\mathrm{Hb}$. Hambatan pada sintesis $\mathrm{Hb}$ mengakibatkan menurunnya kadar $\mathrm{Hb}$ dalam darah. Penurunan kadar $\mathrm{Hb}$ dalam darah berdampak pada kondisi kesehatan seseorang yang terpapar $\mathrm{Pb}$ tersebut ${ }^{4,5}$. Menyatakan keberadaan $\mathrm{Pb}$ di dalam darah menyebabkan gangguan pada sistem haemopoitik, saraf, ginjal, gastrointestinal, kardiovaskular, menurunnya kesadaran (mudah lelah hingga pingsan), hipertensi, endokrin, reproduksi, perubahan tingkah laku, hingga penyakit anemia, dan pencetus karsinogenik.

Pada tahun 2005 dan 2006, Kementerian Negara Lingkungan Hidup $\mathrm{RI}^{6}$ dan Komite Penghapusan Bensin Bertimbal (KPBB) melakukan pemantauan kualitas bahan bakar di beberapa kota besar di Indonesia. Hasil dari pemantauan tersebut menunjukkan bahwa rata-rata kandungan $\mathrm{Pb}$ dalam bensin pada tahun 2005 yaitu sebesar 0,133 gr/l sedangkan pada tahun 2006 rata-rata kandungan $\mathrm{Pb}$ dalam bensin yaitu sebesar $0,038 \mathrm{gr} / 1$. Dari hasil pemantauan tersebut dapat dikatakan bahwa penggunaan $\mathrm{Pb}$ dalam bensin pada saat itu sudah mengalami penurunan yang cukup signifikan, namun efek kesehatan yang ditimbulkan akibat paparan $\mathrm{Pb}$ masih terjadi mengingat waktu akumulasi $\mathrm{Pb}$ dalam tubuh yang cukup lama dan pegawai SPBU termasuk salah satu golongan masyarakat yang paling rentan terhadap paparan $\mathrm{Pb}$.

Penelitian $^{7}$ menunjukkan dari 25 orang responden penelitian, 14 orang responden diantaranya memiliki kadar $\mathrm{Pb}$ dalam darah yang tinggi. Dapat dilihat bahwa ternyata menurunnya penggunaan $\mathrm{Pb}$ dalam bensin tidak serta merta menurunkan kadar $\mathrm{Pb}$ dalam darah seseorang. Darah berfungsi sebagai pembawa oksigen, mekanisme pertahanan tubuh terhadap infeksi dan mekanisme homeostatis ${ }^{8}$.

Direktur Jenderal Minyak dan Gas Bumi dalam keputusannya Nomor 313.K/10/DJM.T/2013 menyatakan bahwa penggunaan atau penginjeksian $\mathrm{Pb}$ dalam jenis bensin 90 (Pertalite) tidak diizinkan. Beberapa hasil penelitian menunjukkan kadar $\mathrm{Pb}$ dalam darah sebagian besar pegawai wanita di beberapa SPBU Tangerang Selatan masih dalam batas aman $(<20 \mu \mathrm{L} / \mathrm{dL})^{9}$, dan beberapa SPBU Kota Kendari juga menunjukkan hal yang sama ${ }^{10}$. $\mathrm{Pb}$ masuk ke dalam tubuh manusia dengan beberapa jalur yaitu melalui makanan, minuman udara, dan perembesan atau penetrasi pada selaput/lapisan kulit $^{11}$. Pb dalam darah menyebabkan inaktivasi enzim d-ALAD dan ferrochelatase ${ }^{12}$. Selain itu, gangguan 
kognisi juga ditemukan pada anak yang terpapar $\mathrm{Pb}$ dengan konsentrasi yang biasa ditemukan atau bahkan pada konsentrasi $<10 \mu \mathrm{L} / \mathrm{dL}$, meskipun belum ada ambang batas yang diidentifikasi untuk efek ini ${ }^{13}$.

Berdasarkan pernyataan yang telah dikemukakan, maka dilakukan penelitian untuk mendeteksi kadar $\mathrm{Pb}$ dalam darah pekerja pengisi bahan bakar di SPBU selang 4 tahun setelah dikeluarkannya larangan penginjeksian senyawa $\mathrm{Pb}$ dalam bensin. Minimnya informasi mengenai dampak $\mathrm{Pb}$ dalam bahan bakar terhadap kesehatan pekerjanya mendorong dilaksanakannya penelitian.

\section{MATERI DAN METODE}

Jumlah sampel yang diambil untuk penelitian yaitu 11 orang pegawai pengisi bahan bakar serta 2 orang pegawai administrasi (kasir) sebagai kontrol. Sampel yang akan diteliti adalah sampel yang mewakili kriteria inklusi sebagai berikut berjenis kelamin laki-laki dan perempuan, dan usia 20-40 tahun. Kriteria eksklusi pada penelitian adalah pegawai pengisi bahan bakar SPBU yang tidak bersedia menjadi responden.

Pegawai SPBU harus mengisi kuesioner terlebih dahulu untuk memilih pegawai yang sesuai dengan kriteria inklusi. Setelah didapatkan pegawai yang sesuai dengan kriteria, peneliti melakukan wawancara lanjutan terhadap pegawai tersebut mengenai gejalagejala kesehatan akibat paparan logam $\mathrm{Pb}$ dalam darah.

Penentuan titik sampling penelitian dilakukan secara purposive sampling dengan kriteria SPBU yang berada di daerah padat kendaraan lalu lintas dan beroperasi selama 24 jam. Pengambilan sampel darah dilakukan di SPBU COCO 21.30204 daerah Plaju, Kota Palembang, Sumatera Selatan. Penentuan responden yang akan diambil sampel darahnya dilakukan dengan teknik purposive sampling dengan mempertimbangkan kriteria inklusi yang telah ditentukan.

\section{Pengambilan Sampel Darah}

Sampel darah yang dibutuhkan sebanyak $5 \mathrm{cc}$. Lengan diikat kencang dengan karet pengikat/torniquet kemudian tentukan daerah vena yang akan diambil darahnya dan sapukan bagian vena tersebut dengan kapas beralkohol (70\%). Suntikkan jarum spuit pada bagian vena dan darah akan otomatis tertarik masuk ke dalam spuit. Setelah mendapatkan volume darah yang dibutuhkan, letakkan kapas kering di daerah penusukan jarum dan jarum spuit langsung ditarik perlahan. Kemudian ikatan tali torniquet dilepas. Sampel darah langsung dimasukkan ke dalam tabung. Tabung kemudian di labeli dengan menuliskan nomor urutan pengambilan sampel darah pada responden ${ }^{14}$. Sampel darah yang telah disimpan di dalam tabung kemudian dibawa ke laboratorium menggunakan cool box untuk menjaga keawetan sampel darah.

\section{Pengukuran kadar Pb dalam darah}

Prosedur kerja sesuai yang dikeluarkan oleh pihak Shimadzu Corporation selaku produsen alat AAS Shimadzu 6300. Sebanyak 2 cc sampel darah diambil dan ditambahkan $10 \mathrm{ml}$ asam nitrat (HNO3). Lalu dipanaskan di hot plate dengan suhu $120^{\circ} \mathrm{C}$ hingga jernih. Setelah mencapai jernih, sampel langsung disaring di labu ukur $10 \mathrm{ml}$ menggunakan kertas saring Whatmann. Sampel kemudian diukur di spektrofotometer. Sesuai dengan standar kerja Laboratorium Kimia Kesehatan dan Toksikologi BBLK, Kota Palembang, untuk pengukuran kadar Pb dalam darah memiliki nilai Method Detection Limit (MDL) $\mathrm{Pb}$ sebesar $\geq 2,995 \mathrm{ng} / \mathrm{ml}$.

\section{HASIL DAN PEMBAHASAN}

Hasil deteksi kadar $\mathrm{Pb}$ dalam darah pegawai SPBU disajikan pada Tabel 1 . Kadar $\mathrm{Pb}$ dalam darah semua responden uji dinyatakan sebagai ttd atau tidak terdeteksi. Hal ini disebabkan kadar $\mathrm{Pb}$ dalam darah bernilai negatif dan berada di bawah batas nilai MDL $\mathrm{Pb}$ pada alat spektrofotometer SSA 6300 yaitu sebesar $\geq 2,995 \mathrm{ng} / \mathrm{ml}$. Nilai negatif menandakan kadar $\mathrm{Pb}$ sangat kecil dalam darah semua responden Spektrofotometer hanya mampu mendeteksi kadar $\mathrm{Pb}$ terendah $(\geq 2,995 \mathrm{ng} / \mathrm{ml})$. Hasil analisis memberikan indikasi darah pegawaai SPBU di daerah Plaju masuk dalam kategori normal. $\mathrm{Pb}$ dalam darah kontrol juga tidak terdeteksi karena konsentrasi $\mathrm{Pb}$ di bawah nilai MDL Pb $(\geq 2,995 \mathrm{ng} / \mathrm{ml})$. Oleh karena itu dinyatakan kadar $\mathrm{Pb}$ dalam darah pegawai pengisi bahan bakar dan pegawai administrasi di SPBU Plaju ini masih tergolong normal.

Kadar $\mathrm{Pb}$ dalam darah responden penelitian tergolong normal juga ditemukan pada penelitian ${ }^{9}$. Penelitian ini dilakukan terhadap pegawai SPBU berjenis kelamin wanita di Tangerang Selatan dengan hasil yaitu kadar $\mathrm{Pb}$ dalam darah sebagian besar pegawai wanita masih dalam batas aman $(<20 \mu \mathrm{L} / \mathrm{dL})$.

Perbandingan kadar $\mathrm{Pb}$ dalam darah pengisi bahan bakar di SPBU pada dua penelitian diatas bisa membuktikan penggunaan $\mathrm{Pb}$ dalam bensin memang telah menurun ${ }^{18}$. Namun diduga, tidak terdeteksinya $\mathrm{Pb}$ dalam darah pegawai pengisi bahan bakar di SPBU Plaju juga akibat pajanan $\mathrm{Pb}$ yang rendah. Untuk membuktikannya perlu dilakukan pengukuran secara rutin dan berkala terhadap kadar $\mathrm{Pb}$ dalam darah pegawai pengisi bahan bakar di SPBU. Paparan $\mathrm{Pb}$ di luar lingkungan SPBU ditambah dengan kondisi jalan raya yang padat kendaraan bermotor meningkatkan bahaya masuknya $\mathrm{Pb}$ ke dalam tubuh. 
Tabel 1. Hasil Pemeriksaan Kadar Pb dalam Darah Seluruh Responden

\begin{tabular}{|c|c|c|c|c|c|c|c|}
\hline No & Usia & $\begin{array}{c}\text { Jenis } \\
\text { Kelamin }\end{array}$ & $\begin{array}{l}\text { Lama } \\
\text { Kerja }\end{array}$ & $\begin{array}{l}\text { Durasi } \\
\text { Kerja }\end{array}$ & $\begin{array}{c}\text { Kebiasaan } \\
\text { Merokok }\end{array}$ & $\begin{array}{c}\text { Penggunaan Alat } \\
\text { Pelindung Diri } \\
\text { (APD) }\end{array}$ & $\begin{array}{c}\text { Kadar Pb } \\
(\mathbf{n g} / \mathbf{m l})\end{array}$ \\
\hline 1 & 29 tahun & Laki-laki & 2 tahun & 8 jam & $\mathrm{Ya}$ & $\mathrm{Ya}$ & $*$ Ttd \\
\hline 2 & 22 tahun & Perempuan & 2 tahun & 8 jam & Tidak & $\mathrm{Ya}$ & $\mathrm{Ttd}$ \\
\hline 3 & 30 tahun & Laki-laki & 2 tahun & 8 jam & $\mathrm{Ya}$ & $\mathrm{Ya}$ & Ttd \\
\hline 4 & 27 tahun & Laki-laki & 5 tahun & 8 jam & $\mathrm{Ya}$ & $\mathrm{Ya}$ & Ttd \\
\hline 5 & 27 tahun & Perempuan & $>5$ tahun & 8 jam & Tidak & $\mathrm{Ya}$ & Ttd \\
\hline 6 & 34 tahun & Laki-laki & $>5$ tahun & $>8 \mathrm{jam}$ & Ya & $\mathrm{Ya}$ & Ttd \\
\hline 7 & 20 tahun & Perempuan & 2 tahun & 8 jam & Tidak & Tidak & Ttd \\
\hline 8 & 20 tahun & Laki-laki & 2 tahun & $>8 \mathrm{jam}$ & $\mathrm{Ya}$ & $\mathrm{Ya}$ & Ttd \\
\hline 9 & 28 tahun & Laki-laki & $>5$ tahun & 8 jam & Tidak & $\mathrm{Ya}$ & Ttd \\
\hline 10 & 24 tahun & Laki-laki & 4 tahun & 8 jam & Tidak & $\mathrm{Ya}$ & Ttd \\
\hline 11 & 21 tahun & Perempuan & 4 tahun & 8 jam & Tidak & Tidak & Ttd \\
\hline
\end{tabular}

*Ttd: tidak terdeteksi

Sumber : Laboratorium Kimia Kesehatan dan Toksikologi BBLK, Kota Palembang, Sumatera Selatan (2017)

Dampak kesehatan pajanan $\mathrm{Pb}$ terhadap gangguan sistem haemotopoetik terjadi lebih dini dibandingkan dengan gejala yang lainnya. Senyawa timbal yang terdapat dalam tubuh akan mengikat gugus aktif enzim ALAD. Ikatan yang terbentuk antara logam timbal dengan gugus ALAD tersebut akan mengakibatkan pembentukan intermediet ini tidak dapat berlangsung ${ }^{11}$. Hipertensi dapat terjadi karena $\mathrm{Pb}$ inorganik menyebabkan kontraksi sistem pembuluh darah perifer ${ }^{15}$. Oleh karena korteks prefrontal bertanggung jawab atas perhatian, pengambilan keputusan yang kompleks, dan mengatur perilaku sosial, perbedaan dalam ukuran dan fungsinya dapat menjelaskan masalah kognitif dan perilaku yang terlihat dengan paparan timbal ${ }^{16,17}$.

Dinyatakan juga bahwa gangguan kesehatan akibat pajanan $\mathrm{Pb}$ menyebabkan menurunnya kadar haemoglobin darah, hipertensi (tekanan darah sistole dan diastole), sakit kepala, menurunnya daya ingat, sukar berkonsentrasi, dan sakit pada otot dan tulang ${ }^{11}$. Penurunan gairah seksual pada wanita dan pria yang bekerja terpapar $\mathrm{Pb}$, serta menyebabkan gangguan reproduksi yang menyebabkan kelainan pada janin, peningkatan kasus infertil, abortus spontan, gangguan haid, bayi lahir mati ${ }^{18}$. $\mathrm{Pb}$ juga menyebabkan penurunan IQ anak balita ${ }^{19}$.

${ }^{17} \mathrm{~Pb}$ mampu melintasi brain blood barrier dan akumulasi $\mathrm{Pb}$ dalam otak memicu agresivitas dan perilaku sosial. Perilaku antisosial digambarkan sebagai perilaku yang tidak diinginkan akibat gangguan kepribadian, namun tidak dapat disamakan dengan kriminalitas meskipun keduanya saling berhubungan. Peningkatan kadar $\mathrm{Pb}$ darah akan mempengaruhi proses penghantaran neurotransmiter di sinaps. Ion $\mathrm{Pb}+$ akan menggantikan atau menghambat fungsi ion $\mathrm{Ca} 2+$ yang secara alami menjalankan fungsi sebagai pendorong vesikel neurotransmiter untuk berekositosis ${ }^{13,19}$.

Pembuluh darah mengandung sel otot yang membantu menyesuaikan diri dengan lingkungan yang berubah.Timbal adalah racun sejati yang tidak memiliki peran penting dalam tubuh. Karakter timbal yang sangat mirip kalsium yang berperan penting dalam kimia otak, menyebabkan timbal dapat menyelinap ke otak dan terlindungi dengan baik. Timbal kemudian mengganggu pergerakan dan penyimpanan kalsium di dalam sel, meningkatkan stres sel, yang dapat menyebabkan kematian neuron dan sel-sel otak lainnya. Efek timbal pada jantung dan pembuluh darah menyebabkan seseorang beresiko lebih tinggi mengalami tekanan darah tinggi, penyakit arteri koroner, dan stroke di kemudian hari ${ }^{19}$.

Timbal masuk ke dalam darah menempel pada eritrosit, timbal bersifat perusak sehingga timbal yang menempel pada eritrosit akan membuat eritrosit lisis/hancur sebelum waktunya regenerasi. Sifat kerusakan timbal bersifat fluktuatif sesuai dengan intensitas paparan dan waktu regenerasi eritrosit, walaupun disisi lain ketika paparan terus menerus $^{20}$.

\section{SIMPULAN}

Berdasarkan penelitian disimpulkan bahwa (1) $\mathrm{Pb}$ tidak ditemukan dalam darah semua responden dan kontrol, (2) Tidak terdeteksinya $\mathrm{Pb}$ diduga akibat pajanan $\mathrm{Pb}$ yang rendah pada pekerja dan digunakannya alat pelindung diri selama bekerja di SPBU, (3) deteksi kadar Pb perlu dilakukan secara rutin dan berkala untuk menghindari terjadinya gangguan kesehatan pada pekerja SPBU. 


\section{DAFTAR PUSTAKA}

1. Oxtoby DW, Gillis HP, Nachtrieb NH. PrinsipPrinsip Kimia Modern Edisi Keempat Jilid II. Jakarta; 2003.

2. Environmental Protection Agency. Toxics Release Inventory Executive Summary. US; 2003.

3. Harmening, Denise M. Modern Blood Banking \& Transfusion Practices 6th Edition. Philadelphia; 2008.

4. Mifbakhuddin, Wahyuningsih NE, Suhartono. Hubungan Kadar Pb dalam Darah dengan Profil Darah pada Petugas Operator Stasiun Pengisian Bahan Bakar Umum di Kota Semarang Timur. Jurnal Kesehatan Lingkungan Indonesia 2007, 6(1): 6-12.

5. Rompas RM. Toksikologi Kelautan. Jakarta; 2010.

6. Peraturan Menteri Negara Lingkungan Hidup No.05 tahun 2006 tentang Ambang Batas Emisi Gas Buang Kendaraan Bermotor Lama. Jakarta; 2006.

7. Rosyidah H, Djannah SN. Hubungan Antara Kadar $\mathrm{Pb}$ dalam Darah dengan Kejadian Hipertensi pada Operator SPBU di Kota Yogyakarta. Jurnal Kesehatan Masyarakat, 2010, 4(2): 104-111.

8. Alberts B, Johnson A, Lewis J, Morgan D, Raff M, Roberts K, \& Walter P. Molecular Biology of the Cell: Sixth Edition. New York; 2015.

9. Kementerian Energi dan Sumber Daya Mineral RI. Standar dan Mutu (Spesifikasi) Bahan Bakar Minyak Jenis Bensin 90 yang Dipasarkan di dalam Negeri. Jakarta: 2013

10. Kementerian Lingkungan Hidup RI. Indonesian Fuel Quality Report. Jakarta; 2006

11. Laila NN, Shofwati I. Kadar Timbal Darah dan Keluhan Kesehatan pada Operator Wanita SPBU. Jurnal Kesehatan Reproduksi 2013, 4(1): 41-49.

12. Suhendro, P Soedibyo H, \& Purnomo W. Kandungan Timbal Dalam Darah Dan Dampak Kesehatan Pada Pengemudi Bus Kota AC dan
Non AC Di Kota Surabaya. Jurnal Kesehatan Lingkungan 2007, 3(2): 127-136.

13. Maskinah E, Suhartono, \& Wahyuningsih NE. Hubungan Kadar Timbal Dalam Darah Dengan Jumlah Eritrosit Pada Siswa Sekolah Dasar. Jurnal Kesehatan Lingkungan Indonesia 2016, 15(2): 4245.

14. Chairlan \& Lestari E. Pedoman Teknik Dasar untuk Laboratorium Kesehatan Edisi 2. Jakarta; 2004.

15. Hadi A. Penentuan Batas Deteksi Metode (Method Detection Level) dan Batas Kuantifikasi (Limit of Quantitation) Pengujian Sulfida dalam Air Limbah dengan Biru Metilen Secara Spektrofotometer. Jurnal Ecolab 2010, 4(2): 7080

16. Wigati, Sukowati, Lestari EW, \& Andries H. Komposisi Parasit Malaria di Daerah Lombok Barat Berdasarkan Malariometric Survey (MS). Jurnal Zoo Indonesia 2011, 20(2): 11-15.

17. Suciani S. Kadar Timbal dalam Darah Polisi Lalu Lintas dan Hubungannya dengan Kadar Hemoglobin. Tesis. Semarang; 2007.

18. Rizkiawati A. Faktor-faktor yang Berhubungan dengan Kadar Hemoglobin (Hb) dalam Darah pada Tukang Becak di Pasar Mranggen Demak. Jurnal Kesehatan Masyarakat 2012, 1(2): 663-669.

19. Pramono JS, Purwanto H, \& Hendri. Analisis Kadar Hemoglobin Ditinjau dari Indeks Massa Tubuh, Pola Makan dan Lama Jam Kerja pada Wanita Pekerja Dinas Pertamanan. Jurnal Husada Mahakam 2014, 3(8): 389-442.

20. Platt, S. \& L. Garosi. Small Animal Neurological Emergencies. CRC Press. Florida; 2012.

21. Zhang X, Yang L, Li Y, Li H, Wang W, \& Ye B. Impacts of Lead/Zinc Mining and Smelting on The Environmental and Human Health in China. Environ. Monit. And Assess 2012, 184(4): 22612273 . 